\title{
Professional Motivation Formation of Future Specialists under the Conditions of Regional Educational Complex
}

\author{
Elena Mikhaylovna Kargina ${ }^{1}$ \\ ${ }^{1}$ Penza State University of Architecture and Construction, Penza, Russia \\ Correspondence: Elena Mikhaylovna Kargina, Department of Foreign Languages, Penza State University of \\ Architecture and Construction, Titov Street 28, 440028 Penza, Russia. E-mail: kargina-elena@mail.ru
}

Received: February 28, 2015

Accepted: March 31, 2015 Online Published: June 28, 2015

doi:10.5539/ies.v8n7p44

URL: http://dx.doi.org/10.5539/ies.v8n7p44

\begin{abstract}
Motivation plays the leading role in the organization of the personality structure. It is a driving force of the activity. Motivation accounts for the behavior and activity and has a great impact on professional self-determination and person's satisfaction with the work. The problem of professional motivation formation of a future specialist is considered in the article. The professional motivation is defined as an action of concrete motives that facilitate the decision of choosing a future profession and provide a long performance of professional duties. The research was conducted on the basis of Penza State University of Architecture and Construction and the Association "University Educational Complex" including various stages of education. Efficiency of continuity of professional motivation formation of future specialist at all grade levels is noted.
\end{abstract}

Keywords: professional motivation, future specialist, regional educational complex, grade levels, continuity

\section{Introduction}

Standard and substantial bases of professional activity induce modern specialists to manifest both profound professional knowledge or skills and interests in the process of activity and in the results of work (Rani \& Kumar-Lenka, 2012).

Interest of the personality in productive professional self-expression is shown under the influence of a set of factors among which an important role is played by the professional motivation formed in the course of vocational guidance and preparation (Batyshev, 1998).

The traditional model of vocational guidance of the personality directly relies on society requirements in the considered region. A future specialist isn't trained for a choice of the future professional activity. The changes which happen in the course of professional activity and, respectively, in vocational guidance of future specialist, increase the importance of a subjective basis of a professional choice (Kargina, 2015). It reveals the problem to form early motivation of professional self-determination (Côté \& Levine, 1997; Federici \& Skaalvikm, 2014). At present time the interests, tendencies, requirements and abilities of students become a decisive factor while choosing one's professional activity (Kutty, 2014).

Establishments of the general and professional education purposefully look for ways of professionalizing of training at all stages of educational process. The aim of school programs reforming is to change the content of education offering students the modern training material according to the development of society, science, technology as well as to develop a system of the gained knowledge demanded by their future professional activity (Pavlova, 2009). They stimulate formation and development of professional motivation of future specialists.

Methods and technologies of organization of personality training at different stages have to correspond, on the one hand, to the reached level of development of students, and on the other hand to motivate them to professional self-determination.

Among the most essential features of professional motivation formation there are certain principles of education system development. They are regional orientation, versatility, multilevelness, integration with educational institutions of secondary professional education (Cervero, 2000; Friedman \& Phillips, 2004; Miroshnichenko \& Gaivoronskaya, 2014). Integration of educational programs of various education levels within a higher educational institution has been widely applied recently. 
Creation of the university educational complexes uniting the establishments of preschool, general and professional education became one of realization forms of the above-mentioned innovative principles. An example of a versatile educational complex is Association "University Educational Complex" functioning on the basis of Penza State University of Architecture and Construction (Kargina, 2008). This complex includes kindergartens, schools, lyceums, colleges.

The model of the personality entry into a profession through a university educational complex differ from a traditional way of professional formation of the personality. The activities of a university educational complex for vocational guidance of students realizing the principles of sequence and continuity in education promote formation of professional motivation of future specialist at all grade levels.

\section{Method}

University Educational Complex promotes formation of a direct professional motive that provides higher quality of vocational training of a specialist.

For practical justification of this hypothetical statement we developed the research algorithm including the stating experiment, the forming experiment, productive and estimating experiment.

The purpose of the initial stating experiment is defined as confirming of formation level of professional motivation of future specialists at the time of the forming experiment beginning (experiment was organized on the basis of University Educational Complex).

The task of the stating experiment is to determine the initial level of professional motivation formation in control and experimental groups (Table 1).

Table 1. Groups of the students and graduates of association "University Educational Complex"

\begin{tabular}{|c|c|}
\hline Control group & Experimental group \\
\hline $\begin{array}{l}\text { 1. The students who finished traditional } \\
\text { educational institution and begin to study in a } \\
\text { higher educational institution of Association } \\
\text { "University Educational Complex" (Penza State } \\
\text { University of Architecture and Construction). }\end{array}$ & $\begin{array}{l}\text { 1. The students who finished traditional } \\
\text { educational institution and begin to study in a } \\
\text { higher educational institution of Association } \\
\text { "University Educational Complex" (Penza State } \\
\text { University of Architecture and Construction). }\end{array}$ \\
\hline $\begin{array}{l}\text { 2. The graduates ( } 4-6 \text { course) of Penza State } \\
\text { University of Architecture and Construction who } \\
\text { entered the Association "University Educational } \\
\text { Complex" from traditional educational } \\
\text { institutions. }\end{array}$ & $\begin{array}{l}\text { 2. The graduates ( } 4-6 \text { course) of Penza State } \\
\text { University of Architecture and Construction who } \\
\text { entered the Association "University Educational } \\
\text { Complex" from traditional educational } \\
\text { institutions. }\end{array}$ \\
\hline $\begin{array}{l}\text { 3. The working graduates of Penza State } \\
\text { University of Architecture and Construction (3-5 } \\
\text { years) who entered the university of Association } \\
\text { from traditional educational institution. }\end{array}$ & $\begin{array}{l}\text { 3. The working graduates of Penza State } \\
\text { University of Architecture and Construction (3-5 } \\
\text { years) who entered the university of Association } \\
\text { from traditional educational institution. }\end{array}$ \\
\hline
\end{tabular}

Having determined the initial level of professional motivation formation of future specialists we planned to carry out the forming experiment which purpose was the formation of professional motivation at the University Educational Complex.

The tasks of the forming experiment are:

- Implementation of the social and pedagogical projects aiming at forming professional motivation of future specialists;

- Application of opportunities of collective and group activity of students and teachers of association "university educational complex" for formation of professional motivation of future specialists;

- Introduction professionally oriented elements into teaching general education subjects.

The purpose of productive and estimated experiment was determined as confirming the level of forming professional motivation of future specialists reached during the forming experiment stage.

The problems of productive and estimated experiment were to determine the level of professional motivation 
formation reached during forming experiment stage in control and experimental groups (Table 1).

To study the entrance motivation and the choice of future specialty of the Penza State University of Architecture and Construction the students of control and experimental groups were asked the following questions:

- Why did you choose this faculty (specialty)?

- Why did you choose this higher education institution (Penza State University of Architecture and Construction)?

- Who influenced your choice of profession?

The applicants answered the first question of the questionnaire as follows: "I chose this profession as I would like to improve the quality of paving. It shouldn't differ from the European countries..." (Maxim K., aged 17, the chosen specialty is "Highways and airfields"). "In Russia there were always bad roads. It's a pity! It's high time to solve this problem. I will try to do my best for it..." (Alexey V., aged 19, the same specialty) or "I was always disturbed by the condition of our roads. I wanted to learn how they are constructed..." (Nikolay E., aged 17, the same specialty). Many answers concern the road situation in Russia. It proves that fact that before entering a higher educational institution students are already aware of the specifics of their future professional activity. It would be natural to such widespread specialties as a lawyer, an economist, a doctor, a teacher...But the specialties at Automobile and road institute of the Penza State University of Architecture and Construction are rather new.

In the experimental group such answers were given: "Technology of transport processes" is the most prestigious specialty! Besides it is highly paid..." (Pavel R., aged 17, the chosen specialty-"Technology of transport processes"), "It is a perspective profession. Always it is possible to find a good job..." (Yury B., aged 17, the same specialty), "This specialty is in great demand now. I see great prospect in future. I always wanted to become a road construction engineer..." (Evgeny F., aged 18, the chosen specialty-"Highways and airfields"), "I chose a perspective profession. Having this specialty it is possible to apply for a job at the Customs, police etc..." (Tatyana P., aged 17, specialty-“Technology of transport processes"). In this selection pragmatic motives prevail. However they show that the choice of students is conscious. They are familiar with specifics of the future profession and see great possibility of practical application of knowledge and skills acquired at the educational institutions of Association "University Educational Complex". The positive motivation of students that promotes interest in receiving a chosen specialty is perspective.

Answering the second question of the questionnaire "Why did you chose this higher education institution?" the applicants were almost unanimous. The following answers dominate. "At school I learned about the specialty "Technology of Transport Processes". Such specialty is trained only at the Penza State University of Architecture and Construction..." (Peter P., 17 years) or "I graduated from automobile and road technical college. I wanted to expand the gained knowledge at the automobile and road institute of the Penza state University of Architecture and Construction..." (Alexey K., aged 19, specialty-"Highways and airfields"). The answers of students show the orientation on concrete specialization trained at the establishments of the general and primary professional education of University Educational Complex of Penza State University of Architecture and Construction is visible. Future applicants were initially oriented the specialties existing at the Penza state University of Architecture and Construction. Students can realize need for receiving a concrete profession in the higher education institution heading Association "University Educational Complex" (Penza State University of Architecture and Construction).

The question "Who influenced your choice of profession?" in experimental group was answered as follows:

- Teachers at school, at gymnasium, at technical college- $48.7 \%$

- Own choice- $20 \%$

- Parents (have such specialty) $-14.5 \%$

- $\quad$ Relatives, acquaintances- $10.8 \%$

- Friends (already studying at Penza State University of Architecture and Construction)-6\%

Similar results testify that most of the choice of specialty of future students was created as a result of training in educational institutions of University Educational Complex of Penza State University of Architecture and Construction: at schools of Association (in case of receiving the general education) or technical colleges of Association (in case of receiving primary professional education). In establishments of Association "University Educational Complex" students were oriented in choice of profession, received the first data on the interested specialty and learned about the ways of further education. So the first-year student Alexander B. wrote in the 
essay "My Future Profession": "This year I finished school, but long before I knew that my future training is connected with Penza State University of Architecture and Construction. After the ninth grade I chose training at a profile class specializing automobiles and roads. Some years ago I had only the general ideas of this specialty. But I liked cars and everything that is connected with them very much. Being a school leaver I learned what specifically professions can be received on this profile what each of them is about. Since then I am sure that my profile is 'Technology of Transport Processes'. Now, having become a student, I am convinced of it more and more ..."

The answer "myself, it is my own choice" (the second place in popularity-20\%) in most cases, isn't sincere. Students (possible unconsciously) were influenced by teachers, parents, friends, mass media etc. But this influence led to that fact that the motive of a choice of a certain specialty became true, own for the applicant. It gives students the feeling of independence and responsibility for the choice.

Parents (that is visible from results of research-14.5\%) also have a great influence on the choice of profession for students. In this group it is possible to follow some tendencies:

- Some appliants want to carry on family tradition and choose the same specialty as their parents: "My mother graduated from the Penza State University of Architecture and Construction and advised me to enter it too..." (Nikolay P., 17 years).

- Other group of applicants gave the similar answer taking their parents as an example. "My life was connected with my father's occupation and I don't imagine a different profession. But I want to get more profound knowledge of this specialty therefore I decided to graduate..." (Yury B., 17 years).

Relatives, acquaintances (10.8\%) and friends (6\%) influenced the choice of a higher education institution and specialty less. "Many acquaintances from my village are studying here. I decided to try, too..." (Ekaterina S., aged 17). In the experimental group there is also a share of false, casual motives.

The answers of the first three questions in the control group are much different. Their analysis shows that the specialty choice motives in most cases are false: "I chose this specialty almost by incident. I didn't know that it is connected with roads..." is written by a first-year student Sergey M., aged 18. In many answers there is the only desire to get a diploma. "I chose this specialty as I need to have a diploma of higher education." (Vladimir S., 18 years). This student found it difficult to explain the need of receiving the diploma of this specialty. In this case his answer is probably affected by the prestige of training at higher education institution. However, without understanding the possibility of the specialty practical application the diploma won't bring benefit to neither a university graduate, nor national economy (James, Baldwin, \& McInnis, 1999).

In the control group the question "Who influenced your choice of profession?" was answered as follows:

- $\quad$ Parents, relatives-61\%

- Friends $-20 \%$

- School teachers $-10 \%$

- The choice was absolutely casual-9\%

The received results show that the parents have the maximum influence on future students' replies. "My mother had great impact on my choice. She approved this higher education institution." (Roman V., 18 years), "Parents wanted me to get this profession. But I also enjoy this profession." (Maxim I., 17 years), "The father as he had studied here had great impact on the choice." (Elena S., 17 years). As similar answers show the passive part is assigned to entrants. In the first case the higher education institution was approved by the mother, in the second parents wanted their children to get such profession. A first-year student, just to justify, writes that he himself is eager to have this profession too.

The similar tendency has both positive and negative items:

- On the one hand, the positive moment is the fact that young people are much subjected to the influence of their parents or relatives. It is possible to be sure that the close loving people wish children only success in life and, therefore, their advice will be directed on achieving the maximum progress for the younger generation. Besides adults or parents have enough experience and already faced the problems of choosing a profession and future employment (Hossler, Schmit, \&Vesper, 1998).

- On the other hand, the specialty choice on the advice of parents can't help to create true motive of professional activity. In most cases parents' advice isn't democratic, it carries an authoritative feature. And the young people lack the opportunity to make one's own decision on the professional activity where it is 
possible to realize oneself.

Friends $(20 \%)$ who influence the choice take the second place: "Most of my friends are studying at the automobile and road faculty of the Penza State University of Architecture and Construction. They told me that they liked to study there. Besides they will always help me..." (Nikolay I., 17 years).

The negative is that the extent of textures influence takes only the third place $(10 \%)$ following parents and...friends!? The professionals who got special pedagogical education don't use all the opportunities and take only a penultimate place in a rating of factors influencing the choice of professional specialization of students. It is necessary to use all means and methods for vocational guidance of students and the message of elementary knowledge, skills of the chosen specialty for it. Everything that is studied at school and then at a higher education institution has to be aimed at professional activity of future specialists first of all (Huang, 2013).

The following questions of the questionnaire were asked to students of 3-4 courses:

- Aren't you disappointed with your future profession after 3 or 4 years of study at the automobile and road institute of Penza State University of Architecture and Construction?

- What profession would you choose again when finished secondary school?

Being satisfied with their first choice the students of 3 or 4 course of study gave the same answer. They named the trained specialty or some that is close to it.

In the control group the following results are received:

- Aren't disappointed in the chosen profession-75\%;

- Are disappointed and wouldn't like to work in the specialty-25\%.

The students of the control group who expressed satisfaction with their future professional activity (75\%) are more careful in the statements: "At the moment I am not disappointed yet while I enjoy my profession." (Alexey I, the 3rd course), "I am not disappointed, but the specialty is difficult. Examinations are especially difficult." (Marína G., the 3rd course). Having studied at the university for 3 or 4 years, the students got acquainted with specifics of the future professional activity and in their professional outlook the positive motivation prevails: "I like to study here very much. I think that I will never be disappointed with this profession" (Yulya G., the 4th course), "Having entered this higher education institution, I definitely didn't know what my future profession is about. But now I am carried away more and more by my specialty." (Nikolay E., 3rd course). In the answers, students show that in return they will use the maximum efforts: "...though it is difficult to study, but I will try very much..." (Alexey S., the 3rd course).

$25 \%$ of students of 3-4 courses aren't satisfied with the chosen profession and wouldn't like to work in the specialty. Answering the question "What profession would you choose again when finished secondary school?" the students gave preference to such specialties as:

- A lawyer ("It is fashionable", "Legal education is is in demand at present", "I want to be aware of laws")-46\%

- An economist, a financier ("it is paid much", "It is possible to get a good job")-28\%

- A policeman-16\%

- Other professions $-10 \%$

Apparently from comments of students, in a choice of new professions, as well as in the first case, false motives prevail. Students are guided by prestige of a profession, having only the extremely superficial idea of contents of the chosen profession. Students don't pay attention to the great extent of specialists having legal or economic education at the labor market and to the difficulties of employment.

Studying of training motives of students of University Educational Complex Association of Penza State University of Architecture and Construction was promoted by using the technique "Studying of motives of the educational activity of students" (Rean, 1994; Yakunin, 1994). This technique suggests students to choose five most significant motives of educational activity from the given list.

The offered list contains the following motives:

1) To become a highly qualified specialist.

2) To get a diploma.

3) To continue training on the subsequent courses with success. 
4) To study and pass examinations successfully.

5) To get a grant constantly.

6) To acquire profound knowledge.

7) To be constantly ready for the new occupations.

8) Not to lag behind in studying the subjects of an educational cycle.

9) Not to lag behind fellow students.

10) To provide success of future professional activity.

11) To fulfill pedagogical requirements.

12) To reach the respect of teachers.

13) To be an example for fellow students.

14) To achieve approval of parents and people around.

15) To avoid condemnation and punishment for bad study.

16) To have intellectual satisfaction.

In the qualitative analysis of the leading motives of educational activity of each student and at all selection the frequency of a choice of this or that motive was determined.

When questioning students of the control group of beginners training at Penza State University of Architecture and Construction the following hierarchical sequence of the leading motives of educational activity was revealed:

1) To gain a diploma

2) To get a grant constantly.

3) To study and pass examinations successfully.

4) Not to lag behind fellow students.

5) To achieve approval of parents and people around.

The chosen motives of educational activity in the control group are distinguished by a pragmatic orientation: to get a diploma, to get a grant. The motives that are directed to the avoidance of failures, but not the achievement of success dominate. Te applicants would like not to lag behind fellow students. They don't want to get profound knowledge but simply want not to be worse than other students. The motive "To study successfully, to pass examinations" is directed to the achievement of this purpose. Entrants of this group study not for themselves, not for future successful professional activity, but for parents or for assessment. Allocation of motive "To achieve approval of parents and people around" testifies to it.

Testing of entrants of the experimental group showed that the leading motives of their educational activity are:

1) To become a highly qualified specialist.

2) To get a diploma.

3) To acquire profound knowledge

4) To provide success of future professional activity.

5) To study and pass examinations successfully.

The dominating motive is the requirement "to become a highly qualified specialist". Having got the general or primary professional education in University Educational Complex, respondents of this group have a clear idea of the contents of the future professional activity and understand that for success in a profession it is necessary to become a highly qualified specialist who has not just sufficient volume of knowledge, abilities, skills, but excellent knowledge.

However in hierarchy of the leading motives of successful activity the motive of getting a diploma is on the second place. This pragmatic motive is present both in the control, and experimental groups. Perhaps, the diploma represents for students peculiar "admission" in future professional life, represents material expression of that knowledge, abilities, skills which were gained during the study at the higher education institution.

The diploma is still more inaccessible symbol of success estimated above, than motive of profound knowledge which takes only the third place after motive of getting a diploma. 
For students of the experimental group the motive "To acquire profound knowledge" is fundamental for realization of motive "To provide success of future professional activity", taking the 4th place in the list of the dominating motives of educational activity.

The last place in the hierarchy of motives is taken by the motive "to study and pass examinations successfully" that is probably, connected with a pragmatic motive "To get a diploma". For many students the purpose is not simply to get a diploma, but the most successful one.

The similar test technique was offered for the graduates of Penza State University of Architecture and Construction (4-5 courses). In the control group as the main motives of training were noted:

1) To study and pass examinations successfully.

2) To get a diploma.

3) To provide success of future professional activity.

4) To acquire profound knowledge

5) Not to lag behind fellow students

The dominating motive in the control group of graduates of Penza State University of Architecture and Construction is the motive "to study and pass examinations successfully". Possibly, this motive is connected with the motive "To get a diploma", taking the second place in the hierarchy, but not with the motive "To acquire profound knowledge", taking only a penultimate place. Good marks for these students aren't an equivalent of excellent knowledge, and serve as the purpose for getting a good diploma.

In the control group of graduates of Penza State University of Architecture and Construction it is possible to remove the following regularity: it is necessary "to study and pass examinations successfully" to "get a diploma". It is necessary "To get a diploma" to "provide success of future professional activity".

The last place in the list of the dominating motives of educational activity for the graduates of Penza State University of Architecture and Construction is taken by the motive "Not to lag behind fellow students" that confirms results of tests for achievement of progress and avoiding of failures. The students who entered the Penza State University of Architecture and Construction from traditional educational institutions kept an orientation on avoiding of failures both during training in higher education institution, and at the beginning of professional activity. The motive "Not to lag behind fellow students" is bright manifestation of this orientation among the graduates of the Penza State University of Architecture and Construction of 4-5 courses.

In the experimental group of final years students of Penza State University of Architecture and Construction such motives of study were mentioned:

1) To become a highly qualified specialist.

2) To acquire profound knowledge

3) To provide success of future professional activity.

4) To study and pass examinations successfully.

5) To get a diploma.

The leading places in this hierarchy are taken by the motives connected with future professional activity: "To become a highly qualified specialist", "To acquire profound knowledge", "To provide success of future professional activity" that testifies to successful professional motivation during training in higher education institution of University Educational Complex.

Two last places are taken by pragmatic motives of study: "to study and pass examinations successfully", "To get a diploma". But comparing with the motives of the graduates from the control group, the motive "To acquire profound knowledge" precedes here the motives of good marks and getting a diploma. The motive of acquiring knowledge dominates. Estimates only accompany knowledge acquisition process, and the diploma is its material expression.

The technique "Motivation of training in higher education institution" (Ilyin, 2002) is directed to the research of professional motivation. The analysis of research results in the control and experimental groups of beginners training at Penza State University of Architecture and Construction by this technique shows the regularity expressed in Table 2. 
Table 2. Results of testing using the technique "Motivation of training in higher education institution" in groups of beginners training at Penza State University of Architecture and Construction

\begin{tabular}{lccc}
\hline Scale & Control group & Experimental group & Maximum result \\
\hline Acquisition of knowledge & 7.6 points & 11.3 points & 12.6 points \\
Mastering a profession & 5.9 points & 8.1 points & 10 points \\
Getting a diploma & 9 points & 4.6 points & 10 points \\
\hline
\end{tabular}

Prevalence of motives on the first two scales testifies to an adequate choice of a profession and satisfaction with it. The technique allows expressing domination of this or that motive quantitatively.

The ratio of the dominating motives in the control and experimental group of beginners training at Penza State University of Architecture and Construction is presented visually on the Figure 1.

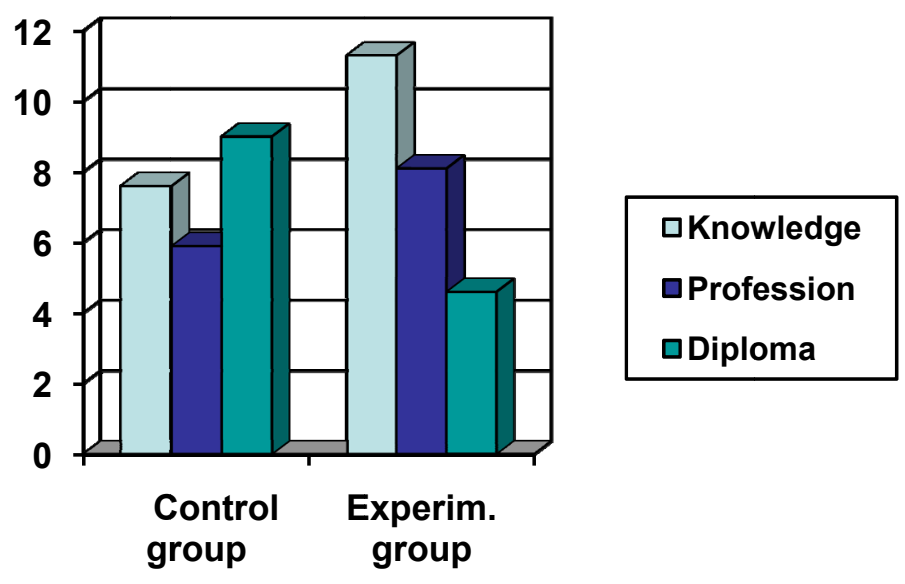

Figure 1. Results of testing using the technique "Motivation of training in higher education institution" in groups of beginners training at Penza State University of Architecture and Construction

In the control group of beginners training at the Penza State University of Architecture and Construction the number of points for "Getting a diploma" (9 points from 10 possible) prevail. A smaller number of points accounts for "Acquisition of knowledge" (7.6 points from 12.6 possible). The minimum result is taken by "Mastering a profession". Quantitative results of this technique confirm the result received in the control group of beginners training at Penza State University of Architecture and Construction by means of the technique "Studying the motives of the educational activity". The dominating motive in the specified group is the motive of getting a diploma. Applicants don't mention the need of knowledge acquisition and practically don't connect the training at a higher education institution with mastering a future profession.

In the experimental group the maximum attention is paid to acquisition of knowledge (11.3 points from 12.6 possible). Thus, under the influence of professional motivation in educational institutions of University Educational Complex, students connect knowledge acquisition with mastering a profession (8.1 points from 10 possible). "Getting a diploma" has only 4.6 points from 10 possible that is minimum. The received result, as well as in the control group, corresponds to the result received by the previous technique determining the leading motives of training in a higher education institution.

The similar technique was offered for students of 4-5 courses training at the Penza State University of Architecture and Construction (Table 3). 
Table 3. Results of testing using the technique "Motivation of training in a higher education institution" in groups of graduates studying at the Penza State University of Architecture and Construction

\begin{tabular}{lccc}
\hline Scale & Control group & Experimental group & Maximum result \\
\hline Acquisition of knowledge & 6.1 points & 10.6 points & 12.6 points \\
Mastering a profession & 7.8 points & 9.4 points & 10 points \\
Getting a diploma & 8.1 points & 5 points & 10 points \\
\hline
\end{tabular}

The ratio of the leading motives of the educational activity in experimental and control groups of graduates training at the Penza State University of Architecture and Construction is represented on the Figure 2:

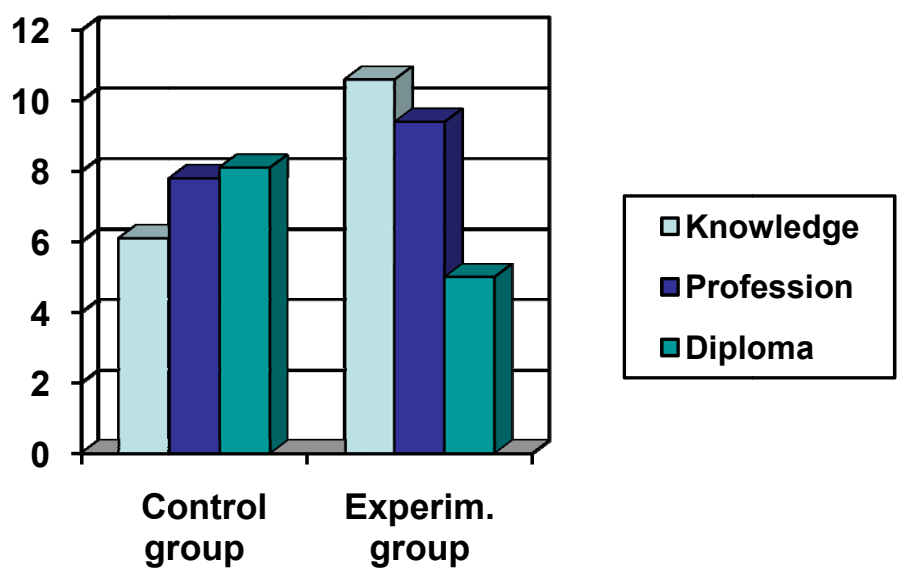

Figure 2. Results of testing using the technique "Motivation of training in a higher education institution" in groups of graduates of the Penza State University of Architecture and Construction

In the control group of graduates there appeared considerable changes:

1) "Mastering a profession" that has 5.9 points in the group of beginners training in a higher education institution increased up to 7.8 points in the answers of university graduates. It became possible thanks to professional motivation and professionally focused training in a higher educational institution of University Educational Complex.

2) In the group of applicants the average quantitative result in the item "Acquisition of knowledge" decreased from 7.6 points compared with 6.1 points in the group of graduates. Students began to pay more attention directly to practice of mastering a profession than to pure theoretical knowledge.

3) In the group of beginners the quantitative index in the item "Getting a diploma" decreased from 9 points compared with 8.1 points in the group of graduates. But the result of this item surpasses the results of two other items.

Therefore, despite all positive tendencies in the control group of graduates (increase of points in "Mastering a profession", decrease of indicators in "Getting a diploma"), the dominating motive of educational activity in the control group remained the motive "Getting a diploma". That testifies to falsehood of choice motive of this concrete specialty and a higher education institution. The same result, but without quantitative indicators was received by the previous test technique.

In the experimental group there were also changes:

1) The indicator of "Acquisition of knowledge" decreased from 11.3 points in the group of beginners compared with 10.6 points in the group of graduates. Moreover in the control group it is the evidence of more attention paid to direct mastering a profession than receiving theoretical knowledge, abilities, and skills.

2) As a result of developing the professional motivation in a higher education institution which is carrying on traditions of educational institutions of the University Educational Complex the average result for "Mastering a 
profession" increased from 8.1 to 9.4 points.

3) The result for "Getting a diploma" has also increased. Insignificant increase - from 4.6 points in the group of beginners to 5 points in the group of graduates-allows connecting this fact with the coming graduation from a higher education institution and the excitement accompanied the thesis defense.

In the experimental group the result for the first two items is prevailing. That confirms the validity of a specialty and a higher education institution choice that was made at the pre-university educational institution of University Educational Complex.

The technique "An orientation to engineering activity" (Godlinik, 2005) allows to confirm the desire to have a job within a certain sphere of engineering activity. This technique considers specific characteristics concerning 4 main types of engineering activity.

The received results of the conducted research in the control and experimental groups of beginners training at the Penza State University of Architecture and Construction are shown in the Table 4 and on the Figure 3.

Table 4. Results of a test technique "An orientation to engineering activity" in the groups of beginners training at the Penza State University of Architecture and Construction

\begin{tabular}{lcc}
\hline Kind of activity & Control group & Experimental group \\
\hline Research activity & $2 \%$ & $4 \%$ \\
Design activity & $11 \%$ & $14 \%$ \\
Production activity & $23 \%$ & $74 \%$ \\
Organizing activity & $64 \%$ & $8 \%$ \\
\hline
\end{tabular}

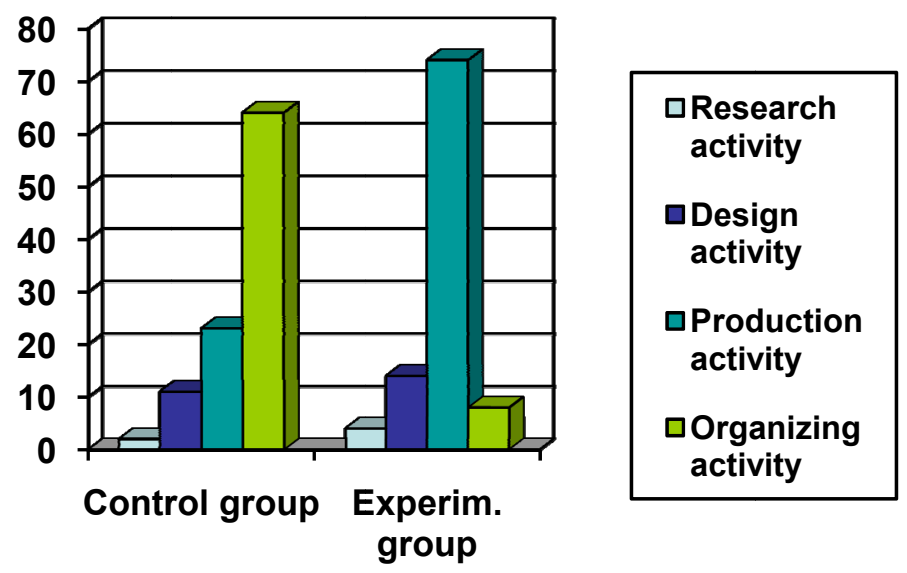

Figure 3. Results of a test technique "An orientation to engineering activity" in the groups of beginners training at the Penza State University of Architecture and Construction

In the experimental group the preference was given to production activity. There were such statements as "to operate cars, mechanisms, devices (to operate, watch, regulate)", "to provide effective, accident-free operation of difficult technical devices".

In the control group the leader is the organizing type of engineering activity. The preference was given to such statements as: "to organize, plan, coordinate the production activity of people", "to develop and introduce modern forms and methods of the organization of work in production".

The similar technique was offered to the control and experimental groups of the graduates in the Penza State University of Architecture and Construction. The following results were received: 
Table 5. Results of a test technique "An orientation to engineering activity" in the groups of the graduates in the Penza State University of Architecture and Construction

\begin{tabular}{lcc}
\hline Kind of activity & Control group & Experimental group \\
\hline Research activity & $3 \%$ & $6 \%$ \\
Design activity & $18 \%$ & $23 \%$ \\
Production activity & $33 \%$ & $65 \%$ \\
Organizing activity & $46 \%$ & $6 \%$ \\
\hline
\end{tabular}

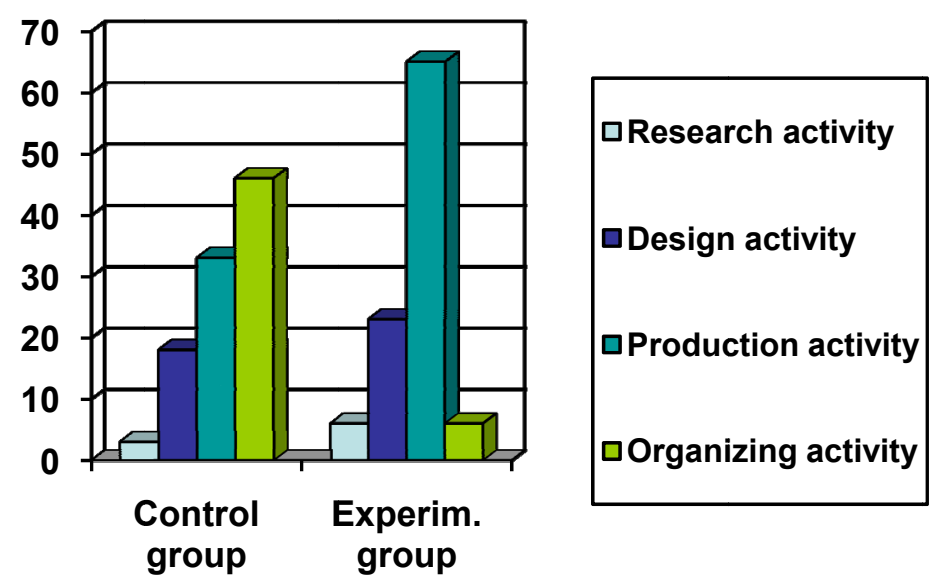

Figure 4. Results of a test technique "An orientation to engineering activity" in the groups of graduates in the Penza State University of Architecture and Construction

Quantitative indices have changed. But the leading types of engineering activity remained. In the experimental group the production type of engineering activity prevails and in the control it is organizing.

\section{Results}

The results of questioning showed that the motives of entrance in the experimental group of students are true and conscious. In their future professional activity they see not only own benefit, but also are aimed at the improvement of social, economic and political status of the country. It proves maturity of specialty choice motives in the experimental group of students.

Having analyzed the changes in the leading motives of educational activity mentioned in control and experimental groups of applicants and graduates of the Penza State University of Architecture and Construction it is possible to draw the following conclusions:

1) In the control group one of the leading motives of educational activity is the motive of getting a diploma. This motive kept the dominating positions up to the graduation from a higher education institution. It proves also falsehood of specialty choice and a higher education institution motives. However final year students mention such motives of educational activity that are connected with their future profession. But they are less important than the motives of receiving marks and the diploma.

2) In the experimental group both at the initial stage of training, and at the graduation from a higher education institution the leading motives of educational activity are professionally directed motives aimed at success of future professional activity. It proves the motives validity of a concrete specialty and a higher education institution choice due to developing some professional motivation in educational institutions of University Educational Complex.

\section{Conclusion}

The results received during skilled and experimental work devoted to the formation of professional motivation for the students of educational institutions of University Educational Complex prove that:

1) University Educational Complex promotes formation of professional demand for future specialists; 
2) Pedagogical process of University educational complex induces students to manifest some activity in the development of professional knowledge, abilities, and skills and to acquire specific significant qualities characteristic for a future specialist;

3) In the course of study at the educational institutions of University educational complex important professional orientation is formed;

4) University Educational Complex promotes formation of professional abilities;

5) University Educational Complex encourages students to think and act independently.

Therefore, training in the educational institutions of University Educational Complex promotes more effective formation of professional motivation of students than training in traditional educational institutions.

\section{References}

Batyshev, S. Y. (1998). Prognostic Orientation of Professional Education. Pedagogics, 6, 22-27

Cervero, R. M. (2000). Trends and Issues in Continuing Professional Education. In V. W. Mott, \& B. J. Daley (Eds.), Charting a Course for Continuing Professional Education; Reframing Professional Practice.

Côté, J. E., \& Levine, C. (1997). Student Motivations, Learning Environments, and Human Capital Acquisition: Toward an Integrated Paradigm of Student Development. Journal of College Student Development, 38(3), 229-243.

Federici, R. A., \& Skaalvikm, E. M. (2014). Students' Perceptions of Emotional and Instrumental Teacher Support: Relations with Motivational and Emotional Responses. International Education Studies, 7(1), 21-36. http://dx.doi.org/10.5539/ies.v7n1p21

Friedman, A., \& Phillips, M. (2004). Continuing Professional Development: Developing a vision. Journal of Education and Work, 17(3), 361-376. http://dx.doi.org/10.1080/1363908042000267432

Godlinik, O. B., \& Solovyova, E. A. (2005). Modern practical psychology. Moscow: Academia.

Hossler, D., Schmit, J., \& Vesper, N. (1998). Going to College: How Social, Economic, and Educational Factors Influence the Decisions Students Make. Johns Hopkins: Baltimore.

Huang, T.-C. (2013). Motivation-Oriented Teaching Model for Certification Education. International Education Studies, 2(6), 84-95. http://dx.doi.org/10.5539/ies.v6n2p84

Ilyin, E. P. (2002). Motivation and motives. St. Petersburg.

James, R., Baldwin, G., \& McInnis, C. (1999). Which University-The Factors Influencing the Choice of Prospective Undergraduates. Canberra: Evaluations and Investigations Program, Higher Education Division, DETYA. http://dx.doi.org/10.1057/9780230114678

Kargina, E. M. (2008). Realization of the Principle of Continuity in Profile Educational Activity of the Association «University Educational Complex». Proceedings of the Volgograd State Pedagogical University, 9, 86-89.

Kargina, E. M. (2015). Efficiency of Training of Engineers in the Conditions of Educational Environment Profiling of Technical Higher Education. Contemporary Engineering Sciences, 2(8), 49-56. http://dx.doi.org/10.12988/ces.2015.412269

Kutty, F. M. (2014). Mapping their Road to University: First-Generation Students' Choice and Decision of University. International Education Studies, 13(7), 49-60. http://dx.doi.org/10.5539/ies.v7n13p49

Miroshnichenko, O. I., \& Gaivoronskaya, Y. V. (2014). Creating Professional Skills through Modern Higher Education. International Education Studies, 9(7), 50-55. http://dx.doi.org/10.5539/ies.v7n9p50

Pavlova, M. (2009). Technology and Vocational Education for Sustainable Development. UNESCO-UNEVOC Book, Series: Technical and Vocational Education and Training: Issues, Concerns and Prospects, Griffith University, QLD, Australia, Springer Science+Business Media B.V.

Rani, R., \& Kumar-Lenka, S. (2012). Motivation and Work Motivation: Concepts, Theories \& Researches. International Journal of Research in IT \& Management, 8(2), 12-22.

Rean, A. A. (1994). Psychology of Pedagogical Activity. Izhevsk.

UNESCO, \& ILO. (2002). Technical and vocational education for the twenty-first century. ILO and UNESCO recommendations, Paris: UNESCO and Geneva: ILO. 
Yakunin, V. A. (1994). Psychology of educational activity of students. Moscow.

\section{Copyrights}

Copyright for this article is retained by the author(s), with first publication rights granted to the journal.

This is an open-access article distributed under the terms and conditions of the Creative Commons Attribution license (http://creativecommons.org/licenses/by/3.0/). 